\title{
Heart Block in Posterior and Anterior Myocardial Infarction
}

\author{
R. M. NORRIS \\ From Green Lane Hospital, Auckland, New Zealand
}

Recent studies involving continuous electrocardiographic monitoring of patients with acute myocardial infarction have shown that second degree atrioventricular (AV) block occurs in 3.5 to 10 per cent, and third degree block in 2.5 to 8 per cent of patients (Meltzer and Kitchell, 1966). Since the outcome of complete heart block complicating infarction is uncertain (Paulk and Hurst, 1966), it has been treated with endocardial pacing (Meltzer, 1967; Scott et al., 1967; Sutton and Chatterjee, 1968), or corticosteroids (Dall and Buchanan, 1962). The present paper describes 34 patients with second or third degree AV block complicating infarction, who were monitored in a Coronary Care Unit; it emphasizes differences in cardiographic characteristics, clinical course, prognosis, and suggested treatment in heart block complicating posterior and anterior infarction.

\section{Patients and Methods}

In a 15-month period between March 1967 and May 1968,276 patients with acute myocardial infarction were studied with continuous cardiographic monitoring in a four-bedded Coronary Care Unit at Green Lane Hospital (Norris, 1968). Arrhythmias were assessed from 10-second tracings taken by nurses hourly, or whenever an arrhythmia was observed on a central oscilloscope screen. Of these patients, 34 developed second or third degree heart block, and they form the basis of this report. Patients who developed first degree heart block only are not included, as the diagnosis of minor degrees of first degree block is not clear cut, and few cases of first degree block were observed which did not progress to second or third degree block.

Patients were admitted as soon as possible after the start of their most severe attack of chest pain ( $43 \%$ within 6 hours of onset), and stayed in the Unit until arrhythmias had been controlled (mean time of stay 5 days). Only patients having at least two of the following three criteria were accepted for the purpose of

Received November 4, 1968. this study as cases of myocardial infarction: (i) characteristic clinical presentation; (ii) $Q$ waves, $S-T$ elevation, or $T$ wave inversion in the cardiogram, with evolutionary change; and (iii) serum aspartate aminotransferase (SGOT) over 45 units $/ \mathrm{ml}$. on one of four successive days. The site of infarction was assessed from serial cardiograms according to the usual criteria (Goldman, 1962).

Heart block was treated by infusion of isoprenaline at 1-5 $\mu$ g. per minute if there were hypotension, or a ventricular rate below 60 a minute in the presence of complete heart block. All 8 patients with anterior infarction received isoprenaline, as did 12 of the 26 patients with posterior infarction. Steroids were not used routinely, and 3 patients with anterior infarction and 4 with posterior infarction received prednisone in a dose of $40 \mathrm{mg}$. daily or equivalent. Transvenous pacing was not used until an Adams-Stokes attack had occurred, when an electrode catheter was immediately inserted through an arm vein into the right ventricle, and the heart was paced with a fixed rate or demand pacemaker. Of the 8 patients .with anterior infarction, 6 were paced; but only 1 patient with posterior infarction was paced.

Due to shortage of beds only patients under 70 years of age were admitted to the Unit, though all patients under 70 were admitted and thus form an unselected group of patients admitted to one hospital.

\section{RESULTS}

A significant difference was found between the clinical course of patients in whom AV block complicated posterior as opposed to anterior infarction, and these differences regarding incidence, cardiographic findings, clinical course, and final outcome are described in Tables I-III.

Incidence of Heart Block. Heart block occurred in 27 per cent of the patients with posterior infarction compared with only 5 per cent of those in whom the infarct was anterior (Table I). In all cases infarction was transmural, as shown by the presence of $Q$ waves and/or $S-T$ segment elevation. Though the mean age of the two groups was similar 
(57 years for posterior and 58 years for anterior infarction), there was an excess of men in the group with posterior infarction.

Cardiographic Characteristics of $A V$ Block. In 17 of the 26 patients with posterior infarcts, heart block did not progress beyond the second degree (Table II), with the Wenckebach phenomenon in 16, two-to-one block in 5, and three-to-one block in 1 patient. Nine patients had complete heart block, though in 6 of these both second and third degree block occurred; 3 patients had third degree block only. In all but 2 patients in whom complete block occurred, the QRS complex was normal in contour, showing that the ventricular pacemaker was situated above the bifurcation of the bundle of His. First degree block (P-R interval greater than $0.20 \mathrm{sec}$.) occurred in 20 patients, and the hourly electrocardiogram strips typically showed a gradual progression from first to second degree block, and then a return to first degree block before normal AV conduction was resumed. When third degree block occurred it was usually preceded and followed by second degree block.

In the 8 patients with heart block complicating anterior infarction, first and second degree block were not observed, and in all cases the block was complete and the QRS complexes were widened to $0.12 \mathrm{sec}$. or greater, indicating a low ventricular pacemaker. Though the numbers of patients with anterior infarction were small, this difference in incidence of purely third degree block in the two groups of monitored patients was highly significant $\left(\chi^{2}=21.7 ; \mathrm{p}<0.001\right)$. In 6 of the 8 patients, the start of the block occurred during monitoring, though as 4 patients died in heart block the return to normal AV conduction was only observed in 4 . Though the onset of complete heart block was abrupt in all 6 patients, QRS complexes in the monitoring lead became widened, and a 12-lead electrocardiogram showed the development of right bundle-branch block some hours before the onset of complete heart block in 5 patients. The QRS widening persisted after AV conduction returned in the 4 patients who died, but gradually disappeared in the 2 survivors.

Time of Onset and Duration of Heart Block. Heart block was transient in all patients, having a mean duration of 1 day 16 hours in cases of posterior infarction, and of 1 day 3 hours in cases of anterior infarction (Table III). The time of onset after the most severe chest pain varied between 4 hours and 7 days (Table III), and there was no significant difference between the time of onset in cases of anterior and posterior infarction.
TABLE I

INCIDENCE OF HEART BLOCK IN POSTERIOR AND ANTERIOR INFARCTION

\begin{tabular}{l|c|c}
\hline & $\begin{array}{c}\text { Posterior } \\
\text { infarct }\end{array}$ & $\begin{array}{c}\text { Anterior } \\
\text { infarct }\end{array}$ \\
\cline { 2 - 3 } $\begin{array}{l}\text { Total no. of cases } \\
\begin{array}{l}\text { Percentage of all patients with } \\
\text { posterior or anterior infarction }\end{array}\end{array}$ & 26 & 8 \\
$\begin{array}{l}\text { Age (yr.) } \\
\text { Sex }\end{array}$ & $\begin{array}{c}57 \\
(40-69)\end{array}$ & 5 \\
$22 \mathrm{M} ; 4 \mathrm{~F}$ & $5 \mathrm{M} ; 3 \mathrm{~F}$ \\
\hline
\end{tabular}

TABLE II

ELECTROCARDIOGRAPHIC CHARACTERISTICS OF HEART BLOCK COMPLICATING POSTERIOR AND ANTERIOR INFARCTION

\begin{tabular}{l|c|c}
\hline & $\begin{array}{c}\text { Posterior } \\
\text { infarct }\end{array}$ & $\begin{array}{c}\text { Anterior } \\
\text { infarct }\end{array}$ \\
\hline Total no. of cases & 26 & 8 \\
Second degree block only & 17 & 0 \\
Second and third degree block & 6 & 0 \\
Third degree block only & 9 & 8 \\
Total patients with third degree block & 20 & 0 \\
$\begin{array}{l}\text { First degree block preceding or following } \\
\text { Widened and third degree block } \\
\text { block } \star\end{array}$ preceding third degree & 0 & 5 \\
Widened QRS in third degree block & 2 & 8 \\
\hline
\end{tabular}

* Not known in 7 patients with posterior and 2 patients with anterior infarction.

TABLE III

CLINICAL COURSE AND PROGNOSIS OF HEART BLOCK COMPLICATING POSTERIOR AND ANTERIOR INFARCTION

\begin{tabular}{|c|c|c|}
\hline & Posterior infarct & Anterior infarct \\
\hline $\begin{array}{l}\text { Time of onset of heart } \\
\text { block after most } \\
\text { severe chest pain* } \\
\text { Mean duration } \\
\text { Adams-Stokes attacks } \\
\text { Mortality }\end{array}$ & $\begin{array}{l}2 \text { dy. } 5 \text { hr. } \\
\text { (4 hr. }-5 \text { dy. } 12 \text { hr.) } \\
1 \text { dy. } 16 \text { hr. } \\
\text { (1 hr. }-5 \text { dy. } 18 \text { hr.) } \\
2 \\
5(19 \%)\end{array}$ & $\begin{array}{c}2 \text { dy. } 18 \mathrm{hr} . \\
\text { (3 hr. }-7 \text { dy. } 3 \mathrm{hr} .) \\
1 \mathrm{dy} .3 \mathrm{hr} . \\
(2 \mathrm{hr} .2 \mathrm{dy} .17 \mathrm{hr} .) \\
8+ \\
6(75 \%)\end{array}$ \\
\hline
\end{tabular}

* Known in 19 and estimated in 5 patients with posterior infarction; known in 6 and estimated in 1 patient with anterior infarction. t Including 2 patients who died in first cardiac arrest.

Incidence of Adams-Stokes Attacks. Only 2 of the 26 patients with posterior infarction had AdamsStokes attacks (Table III). In 1 patient a brief syncopal attack, which was not witnessed, preceded a period of complete heart block lasting 1 hour, while 1 patient had asystole occurring 19 hours after reversion from second to first degree block. By contrast, Adams-Stokes attacks occurred in all 8 patients with heart block complicating anterior infarction, occurring during the period of monitoring in 7 , and in all patients the heart arrested in asystole. In 4 patients, asystole heralded the onset of complete heart block, there being no warning apart from the QRS widening described previously. 
TABLE IV

MODE OF DYING OF PATIENTS WITH HEART BLOCK

\begin{tabular}{|c|c|c|}
\hline & $\begin{array}{c}\text { Posterior } \\
\text { infarct }\end{array}$ & $\begin{array}{c}\text { Anterior } \\
\text { infarct }\end{array}$ \\
\hline $\begin{array}{l}\text { Sudden death } \\
\text { Ventricular fibrillation } \\
\text { "Power failure" } \\
\text { Complete heart block (sudden onset) } \\
\text { Heart failure } \\
\text { Cardiogenic shock } \\
\text { Pulmonary emboli } \\
\end{array}$ & $\frac{1}{\frac{1}{2 \star}}$ & $\begin{array}{l}1 \\
1^{\star} \\
2^{\star} \\
1 \\
1^{\star}\end{array}$ \\
\hline Total & 5 & 6 \\
\hline
\end{tabular}

* In complete heart block at time of death.

TABLE V

CHARACTERISTICS OF HEART BLOCK IN POSTERIOR AND ANTERIOR INFARCTION

\begin{tabular}{|c|c|c|}
\hline & Posterior infarct & Anterior infarct \\
\hline Proportion of infarcts & $27 \%$ & $5 \%$ \\
\hline $\begin{array}{l}\text { having heart } b \\
\text { Type of block }\end{array}$ & $\begin{array}{l}\text { Second degree or } \\
\text { transient third } \\
\text { degree with nor- } \\
\text { mal QRS com- } \\
\text { plexes }\end{array}$ & $\begin{array}{l}\text { Third degree with } \\
\text { widened QRS } \\
\text { complexes }\end{array}$ \\
\hline Preceding abnormality & $\begin{array}{l}\text { First degree heart } \\
\text { block }\end{array}$ & $\begin{array}{l}\text { Right bundle- } \\
\text { branch block }\end{array}$ \\
\hline $\begin{array}{l}\text { Adams-Stokes attacks } \\
\text { Prognosis without treat- } \\
\text { ment }\end{array}$ & $\begin{array}{l}\text { Uncommon } \\
\text { Fair }\end{array}$ & $\begin{array}{l}\text { Common } \\
\text { Poor }\end{array}$ \\
\hline $\begin{array}{l}\text { Recommended treat- } \\
\text { ment }\end{array}$ & $\begin{array}{l}\text { Nil, isoprenaline, } \\
\text { or endocardial } \\
\text { pacing }\end{array}$ & Endocardial pacing \\
\hline
\end{tabular}

Incidence of Ventricular Fibrillation. This was the cause of death in 1 patient with posterior infarction and one with anterior infarction (Table IV), while it was successfully treated in a further 3 patients with posterior infarction. In only 1 patient did it occur while the patient was in block, and this was a patient with posterior infarction who had reverted from third to second degree block, and was receiving an isoprenaline infusion.

Mortality. Five of the $26(19 \%)$ patients with posterior infarction and 6 of the $8(75 \%)$ with anterior infarction died, this difference in mortality between the two groups being statistically significant $\left(\chi^{2}=8.68 ; \mathrm{p}<0.01\right)$. The causes of death are summarized in Table IV, and are described briefly below.

Though 2 of the 5 patients with posterior infarction were in complete heart block at the time of death, the cause of death was considered to be acute circulatory failure in both (Table IV). The patient who died from ventricular fibrillation was not monitored immediately before the arrest, having been transferred to the general ward 3 days previously, but heart block had resolved 3 days before transfer, and attempted resuscitation produced a temporary return of sinus rhythm with normal AV conduction. The fourth patient died from pulmonary emboli after the resolution of block, while the fifth died suddenly, 15 days after restoration of normal conduction and successful treatment of ventricular fibrillation, with sinus bradycardia occurring for about 1 minute after clinical death. Death was thus attributed to "power failure" (Lown et al., 1967), though unfortunately permission for necropsy was not obtained, so that cardiac rupture was not excluded. Necropsies were performed on the other 4 patients, and the presence and site of infarction was confirmed in all.

Of the patients with anterior infarction, 1 died in cardiogenic shock with a heart rate of 50 a minute on $5 \mu \mathrm{g}$. $/ \mathrm{min}$. of isoprenaline, and without a pacemaker, 1 died from heart failure 6 days after reversion to normal $\mathrm{AV}$ conduction, 1 died from ventricular fibrillation 10 days after reversion, while the fourth patient died suddenly with paced QRS complexes occurring for half a minute after clinical death. This patient had previously been in asystole when the pacemaker was turned off temporarily. The remaining 2 patients had complete heart block as a terminal event. Necropsies were performed on 4 patients, and the presence of a recent anterior and septal infarct, with occlusion of the anterior descending branch of the left coronary by recent thrombus or atheroma, was confirmed in all.

\section{Discussion}

Heart block in the present study was a common and usually benign complication of moderately severe posterior infarcts, occurring 2 to 3 days after the onset of infarction, and subsiding spontaneously in 1 to 3 days. It was usually of second degree, and if third degree block occurred it was transient, associated with a high ventricular pacemaker, and usually not accompanied by Adams-Stokes attacks. When heart block complicated anterior infarction, however, heart block was of third degree with widened QRS complexes, Adams-Stokes attacks usually occurred, and the outcome was more likely to be fatal. Whereas first degree block preceded and followed second degree block in posterior infarction, complete heart block in anterior infarction was heralded by right bundle-branch block and a normal $P-R$ interval. These differences between heart block in posterior and anterior infarction are summarized in Table V. Though the number of fatal cases in both groups is relatively small, death seemed to be related more to the over-all severity of the infarct than to the heart block itself, and it was striking that most patients dying in heart block had severe shock and heart failure for some hours before 
death. This agrees with the finding of Paulk and Hurst (1966) that in a group of 43 patients with complete heart block after infarction, no patient died who was not in heart failure, while the mortality rates in patients with mild, moderate, and severe failure and heart block were 30,55 , and 84 per cent, respectively.

The more frequent occurrence of heart block in posterior than in anterior infarction, with its relatively good prognosis, normal QRS duration in complete block, and infrequent Adams-Stokes attacks has been described by other authors (Cohen, Doctor, and Pick, 1958; Courter, Moffat, and Fowler, 1963; Jackson and Bashour, 1967), and it is also agreed that the prognosis of anterior infarction with heart block is more serious (Friedberg, Donoso, and Stein, 1964; Scott et al., 1967). The suggestion from the present study that heart block in anterior infarction is nearly always complete, complicated by AdamsStokes attacks, and heralded by right bundle-branch block rather than first degree block seems not to have been stressed by previous authors. These findings thus require confirmation, though a possible reason for the former difference is that heart block in infarction has been related by previous authors more to its degree than to the site of the infarct causing it.

The reason for the different behaviour of heart block in posterior and anterior infarction lies in the anatomy of the blood supply to the interventricular septum and conducting system of the heart (James and Burch, 1958). Most of the septum is supplied by the anterior descending branch of the left coronary artery, while a variable but small part of the posterior portion including the atrioventricular node and bundle is supplied by the right coronary or, exceptionally, by the circumflex branch of the left coronary. Intercoronary anastomoses between right and left coronaries are particularly well developed in the interventricular septum, and this is presumably one reason for the fact that heart block in myocardial infarction is nearly always transient. Occlusion of the right coronary artery and posterior infarction may cause selective ischaemia or oedema of the AV node and bundle, anastomoses from the anterior descending artery preventing permanent infarction. Anterior infarction, however, may not cause selective ischaemia of the node and bundle of His, but may cause heart block by widespread involvement of more peripheral parts of the conducting system; this implies widespread infarction of the septum, and aberrant or bundle-branch block type of intraventricular conduction, while a normal $\mathrm{P}-\mathrm{R}$ interval preceding and following complete heart block would be expected. The present study suggests that these anatomical considerations may be the principal determinants of prognosis in heart block complicating infarction, and emphasizes the need for further detailed pathological studies. Other workers (Paulk and Hurst, 1966; Meltzer, 1967) have described prognosis in relation to the degree of heart block, whether of second or third degree, but the present results suggest that the site of the infarct is a more important factor.

The predominance of third degree heart block with Adams-Stokes attacks in anterior infarction, and the relatively benign course of patients with heart block and posterior infarction, argue for a different approach to treatment according to the site of the infarct. Immediate endocardial pacing, preferably with a demand pacemaker, is necessary to prevent Adams-Stokes attacks in patients with anterior infarction who develop heart block, but pacing is not considered to be indicated routinely in patients with posterior infarction, even if heart block is complete. Indications for pacing in such patients are thought to be atypical QRS widening, an Adams-Stokes attack, the need to use antiarrhythmic drugs in the presence of complete block, or the presence of circulatory failure and a slow heart rate that cannot be speeded with isoprenaline. This contrasts with the recommendation of Meltzer (1967), and Sutton and Chatterjee (1968), that transvenous electrode catheters should be passed routinely in all patients with second or third degree block, regardless of the site of infarction, or with the practice of Kimball and Killip (1967) who pass pacemaking catheters on 35 per cent of patients admitted to a coronary care unit. The relatively conservative approach to pacing in the present series of patients did not result in any lives being lost from Adams-Stokes attacks, though it is possible that a more rapid ventricular rate might have altered the outcome in the 3 patients who died in complete block and acute circulatory failure, and pacing would be attempted in future for similar cases.

The occurrence of Adams-Stokes attacks as the first manifestation of heart block in anterior infarction in 4 patients described in this paper makes it desirable to identify preceding cardiographic abnormalities, so that the need for pacing can be anticipated. Preliminary observations suggest that right bundle-branch block with left axis deviation is the cause of the QRS widening seen in the monitored lead, and that this indicates incomplete bilateral bundle-branch block (Unger et al., 1958). Further studies are in progress to determine the incidence and prognosis of this abnormality in patients with anterior infarction, and to establish whether it constitutes an indication for transvenous demand 
pacing. Until fuller information is available, all patients with anterior transmural infarction in our Coronary Care Unit have twice daily 12-lead electrocardiograms, and demand pacing is considered in all patients who develop right bundle-branch block.

\section{SUMMARY}

The incidence, electrocardiographic characteristics, prognosis, and treatment of second and third degree heart block complicating acute myocardial infarction are described in 34 patients who had continuous cardiographic monitoring in a coronary care unit. The clinical course in these patients was related to the site of the infarct, heart block in posterior infarction usually running an uncomplicated course and resolving spontaneously in one to three days; Adams-Stokes attacks were uncommon in these patients, and the QRS complex in third degree block was of normal duration. Heart block in anterior infarction was usually complete, AdamsStokes attacks were common, and the QRS duration was prolonged. First degree heart block usually preceded or followed more severe degrees of block in patients with posterior infarcts, while complete heart block in anterior infarction was preceded by right bundle-branch block. The implications regarding pathogenesis and treatment of heart block in infarction are discussed, and it is considered that transvenous pacing is usually not indicated in heart block complicating posterior infarction.

I am grateful to the Visiting Physicians of Green Lane Hospital for permission to report on patients under their care, to Physicians of the Cardiology Unit at Green Lane for assistance with endocardial pacing, and to the nursing and technical staff of the Coronary Care Unit for help at all stages of this work.

\section{REFERENCES}

Cohen, D. B., Doctor, L., and Pick, A. (1958). The significance of atrioventricular block complicating acute myocardial infarction. Amer. Heart F., 55, 215.

Courter, S. R., Moffat, J., and Fowler, N. O. (1963). Advanced atrioventricular block in acute myocardial infarction. Circulation, 27, 1034.

Dall, J. L. C., and Buchanan, J. (1962). Steroid therapy in heart-block following myocardial infarction. Lancet, 2, 8.

Friedberg, C. K., Donoso, E., and Stein, W. G. (1964). Nonsurgical acquired heart block. Ann. N.Y. Acad. Sci., 111, 835.

Goldman, M. J. (1962). Principles of Clinical Electrocardiography, 4th ed., pp. 153-176. Lange Medical Publications, Los Altos, California.

Jackson, A. E., and Bashour, F. A. (1967). Cardiac arrhythmias in acute myocardial infarction. I. Complete heart block and its natural history. Dis. Chest, 51, 31.

James, T. N., and Burch, G. E. (1958). Blood supply of the human interventricular septum. Circulation, 17, 391.

Kimball, J. T., and Killip, T. (1967). In Cardiac Pacing and Cardioversion. American College of Cardiology, New York.

Lown, B., Fakhro, A. M., Hood, W. B., and Thorn, G. W. (1967). The coronary care unit. New perspectives and directions. F. Amer. med. Ass., 199, 188.

Meltzer, L. E. (1967). In Cardiac Pacing and Cardioversion. American College of Cardiology, New York.

- , and Kitchell, J. B. (1966). The incidence of arrhythmias associated with acute myocardial infarction. Progr. cardiovasc. Dis., 9, 50.

Norris, R. M. (1968). Acute coronary care. N.Z. med. F., 67, 470.

Paulk, E. A., Jr., and Hurst, J. W. (1966). Complete heart block in acute myocardial infarction. A clinical evaluation of the intracardiac bipolar catheter pacemaker. Amer. F. Cardiol., 17, 695.

Scott, M. E., Geddes, J. S., Patterson, G. C., Adgey, A. A. J., and Pantridge, J. F. (1967). Management of complete heart block complicating acute myocardial infarction. Lancet, 2, 1382.

Sutton, R., and Chatterjee, K. (1968). Heart-block in myocardial infarction. Lancet, $1,94$.

Unger, P. N., Lesser, M. E., Kugel, V. H., and Lev, M. (1958). The concept of "masquerading" bundlebranch block: an electrocardiographic-pathologic correlation. Circulation, 17, 397. 